\title{
Underused land, brownfields, future use and effects: Browntrans Project outputs
}

\author{
D. Vojkovská, B. Vojvodíková \& B. Macečková \\ Faculty of Civil Engineering VŠB, Technical University of Ostrava, \\ Czech Republic
}

\begin{abstract}
The Czech Republic is one of the smaller states in Central Europe with about 10 million inhabitants. In the frame of problematic of regional development and regional planning issues interregional differences are solved. With regard to the fact Czech Republic is a relatively small country; the conception of regional development by the principle of subsidiarity is transmitted to the level of municipalities. One of the monitored effects, which influence sustainable development, is also the existence of underused land or also previously used land (brownfields). Non-governmental or non-profit institutions may participate in the regeneration or re-using of these areas. The consequences of existence of these areas in concrete municipality are analyzed. The possibility of how these process regenerations were solved in the Czech Republic are indicated in the frame of this article on the example of several localities indicated. An important part of the contribution is devoted to effects which this successful regeneration brought to their surroundings. Examples were deliberately chosen not with investments having the expectation of future profit but with inputs of small financial funds and big enthusiasm which achieved significant regional effects.
\end{abstract}

Keywords: brownfields, cultural heritage, municipality, regeneration, redevelopment, subsidies.

\section{Introduction}

Among other goals, the cohesion policy of the European Union aims at reducing disparities between regions. In the Czech Republic, the principal activities concerning development (since development is considered as a necessary condition for reduction of disparities) are carried out at the level of regions and 
big cities. Smaller municipalities remain in the background, although more than half of the Czech population live in smaller towns and villages [1].

Just like big cities, such smaller municipalities have to deal with sites, which have ceased to perform their functions. Point out, for example, in nearly every municipality in the Votice micro-region (situated in Central Bohemia) there is at least one site, which can be defined as a brownfield site [2]. Before 1990, these sites used to house factories, agricultural buildings or cultural centres. Until 1990, many of these sites had been the principal source of work opportunities for locals and their removal had a considerable impact on the local architecture, and even more so, on the population and its demographic composition. Concentrated on the Tanvald region (situated in North Bohemia), and compared the situation between the years 1990, 2000 and 2011, for example in Klusáček et al. [3]. The first decade was a period of social changes associated with a dramatic increase in unemployment rate, and over the following ten years municipalities tried to redevelop the abandoned sites and restore them to their former functions, which consequently led to the reduction of the unemployment rate.

Therefore it is obvious that the re-use of so-called brownfield sites is one of the crucial tasks in regional development. To incorporate the redevelopment of brownfield sites into the regional land management is one of criteria, as defined by Pahlen et al. [4], for sustainability of land use and urban design. The Project BROWNTRANS Brownfield Regeneration Know-How Transfer - focuses on sharing experience of redevelopment of brownfield sites or underused lands.

The following text about three sites in Northern Moravia should illustrate the significance of locating some firms in small municipalities. It also shows how NGOs or the municipalities can undertake restoration and transformation of abandoned sites. In one of the cases, the municipality performs the role of the developer (thus not only initiating the project, but also executing it). By way of conclusion, each article sums up the principal impact of redevelopment, based on interviews with people involved in each case. The following section presents three particular cases of redevelopment of lands and buildings that had ceased to perform their function and became a burden for the environment. In none of the three cases the redevelopment process was carried out by a private firm aiming at making profit. Although the three sites differ from each other in their present state and past function, their redevelopment has always been primarily aimed at improving the life of people in the neighbourhood.

\section{Old colliery “František” in Horní Suchá}

\subsection{What were the past benefits derived from the site? What was its past function? What was done by way of development?}

The old and now unused coal mine "František" is located in Horní Suchá. The Municipality of Horní Suchá stretches to an area of about $10 \mathrm{~km}^{2}$ and has 4,500 inhabitants. It is one of the smaller towns of the Ostrava-Karviná agglomeration, which has been connected with the coal mining industry for centuries. 
The municipality was founded in 1305. As Figure 1 shows [5], it was a rather small, agricultural village, with a population of several hundred people. When the coal mine "František" was opened in 1911, it significantly affected the agricultural character of the municipality and the composition of its population.

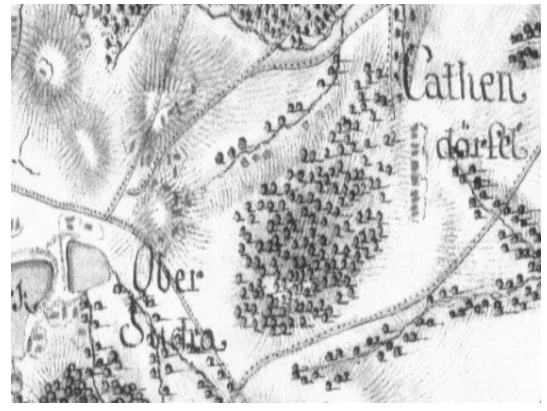

Figure 1: Horní Suchá - I. military maps - era of Joseph II 1764-1768.

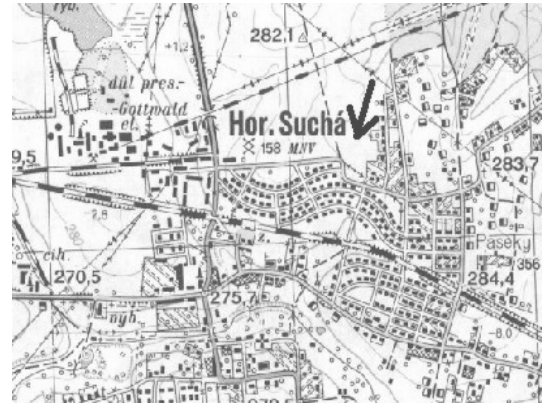

Figure 2: Horní Suchá in 1957.

The construction of the coal mine created a need for labour force, and it was mostly newcomers who started working there. The number of miners changed over the years, and while the mine was in operation there were between 1,200 and 2,500 miners [6]. Figure 2 shows the population density in 1957 [7]. In the northern part of the municipality we can see massive construction of mining houses. In the 1960s the population settled on the current number of 4,500 inhabitants.

\subsection{When did the site ceased to perform its function? How did it affect the environment?}

The coal mine "František" was closed in 1999. Ever since the mining activity was terminated, the unemployment rate was significantly increasing - in comparison with 1997 it was twice as much: $18.60 \%$ and over the following years it rose to $20 \%$. In 2004 the situation got even worse, with the unemployment rate shooting up to $24.10 \%$, the highest number in history so far [8]. Between 1999 and 2002 the premises of the old coal mine were unused. The coal mine was still a property of OKD (a private, coal mining company, which acquired the property in the process of privatization after the fall of communism). By that time most of the coal mines in the Ostrava basin (e.g. the coal mine "Alexander") were closed, which meant that there was a surplus of abandoned or unused coal mines. The unemployment rate in the entire region was extremely high, large companies were reducing their production and the State was supporting constructions of new industrial parks built on greenfield land. The result of such situation was that private owners were not induced to redevelop these sites in any way; on the other side, they were very eager to get rid of them. Thus, in 2002 the old coal mine went in the hands of DIAMO, state 
enterprise, which acquired the coal mine "František" together with other premises of old coal mines for a symbolic price of $1 \mathrm{CZK}$. Although the State had been well aware of the difficult economic situation in the region, it still continued to support industrial parks built on greenfield land and reduction of unemployment in bigger cities. During these years, the municipality had to struggle with unemployment as well as with the social pathological phenomena connected with unemployment, e.g. increase in crime. By the end of 2002 and in 2003 intense negotiations over the possibility of transferring the property to the municipality were conducted. It was also agreed that useless buildings were to be demolished. However, due to the fact that the security guards were dismissed, in a very short time scrap metal collectors devastated the buildings and the public utilities.

\subsection{Who undertook the redevelopment? What were the sources of finance for the redevelopment?}

In 2005 the old coal mine was transferred to the municipality. The municipality intended to build an industrial park on the site, thus compensating for the lack of work opportunities. The whole project has been managed by the municipality, which receives money from government budget but which also has to spend money within the municipality budget on co-financing and other costs. For more detail on the investments and investors see Table 1 [8].

On $4^{\text {th }}$ May 2010 there was the grand opening of the entire industrial park.

Table 1: $\quad$ Principal investing activities prior to the opening of the industrial park.

\begin{tabular}{|l|l|l|l|}
\hline Years & Investments in & Investors & Investments \\
\hline $2006-2007$ & $\begin{array}{l}\text { Restoration of the administrative } \\
\text { building }\end{array}$ & OPIE & $800,000 €$ \\
\hline $2007-2008$ & Construction of the new hall & EU Structural Funds & $800,000 €$ \\
\hline & & Government budget & $800,000 €$ \\
\hline $2006-2007$ & $\begin{array}{l}\text { Infrastructure of the industrial park - } \\
\text { project planning }\end{array}$ & OPIE & $800,000 €$ \\
\hline & Infrastructure of the industrial park & $\begin{array}{l}\text { Government budget } \\
\text { of the Inter- } \\
\text { Departmental } \\
\text { Committee on the } \\
\text { Redevelopment of } \\
\text { the MSR }\end{array}$ & $800,000 €$ \\
\hline
\end{tabular}

\subsection{What were the effects of the redevelopment?}

The entire transformation of the brownfield site into the industrial park had a significant impact on the population. The unemployed inhabitants were enlisted as constructions workers. In 2008 the unemployment rate had already dropped to $13.2 \%$ [1] and it has been going down even more. 


\subsection{Actual impact - present function}

This part is based on an interview with Jan Lipner, Mayor of Horní Suchá. From the very beginning, the municipality intended to transform the old coal mine "František" into an industrial park, which had been in compliance with the landuse plan. Also, there were not many other possibilities. The inhabitants were rather sceptical about any plans for transformation. The project of transformation of the old coal mine "František" into an industrial park originally provided for 1,000 people working in the park. Due to increasing workforce productivity and taking into consideration current modern technologies, it seems more probable that the number of people employed in the industrial park will be about 500 . There is no law, which would provide for preferring the employment of local residents of Horní Suchá, nevertheless, due to the commute costs the number of locals working in the park is significantly increasing. A considerable benefit derived from the project has been the employment of the long-term unemployed, who got the opportunity to work on the construction site. It turned out that a useful solution for the municipality is to hire the long-term unemployed to do community work.

Over time, the citizens of Horní Suchá have become more interested in the issues concerning the industrial park, yet their efforts often lead to a reduction of finances; the municipality must invest in the management of the industrial park. Although the park is two-thirds full, it is still slightly passive and its operation has to be subsidized by the municipality. However, in the near future the situation should improve.

\section{Old colliery “Alexander” in Kunčičky}

\subsection{What were the past benefits derived from the site? What was its past function? What was done by way of development?}

The old coal mine "Alexander" is located in Kunčičky, originally a solely agricultural municipality (it is now an administrative part of the city of Ostrava). The coal mining activity started in 1898 and the coal mine then employed 938 people. Together with the coal mine many mining houses were constructed. In ten years 90 new houses were built. The development of coal mining and the related iron and steel industry brought about significant changes in the local socio-economic environment. In a few decades the farmers turned into industrial workers. Following industrialization in the second half of the $19^{\text {th }}$ century the number of inhabitants rapidly increased (nearly twenty times) [9]. Within twenty years, from 1890 to 1910, following the construction of the mine shaft "Alexander", the population of Kunčičky increased three times (in 1910 it was 4,607 people). In the inter-war years the number of inhabitants still continued to grow. However, population of Kunčičky got to its historically highest number in 1940 (it was 5,646 inhabitants) [11]. 


\subsection{When did the site ceased to perform its function? How did it affect the environment?}

The mining activity in the coal mine "Alexander" was definitively terminated on $31^{\text {st }}$ December 1992 and all activities connected with coal mining were stopped in 1994.

During the period of subdued activity, the look of the coal mine "Alexander" changed significantly. Whereas some of the changes were positive (the demolition of the preparation plant - return to the original layout), other changes corrupted the historic value of the site (demolition of the engine rooms and compressor plant). In 1993, nine buildings together with both mine shafts were proclaimed cultural heritage of the Czech Republic and listed in the Central Register of Cultural Heritage. For a long time, the entire site had been abandoned. The possibilities of redevelopment of the site were made more difficult owing to the fact that the premises were cut off from public utilities and quite far from infrastructure. Also, the expected requirements and demands of the heritage department were a matter of concern. And last but not least, the financial demands of the owners (OKD and, later, DIAMO) were an important issue, too. In 2000 most of the buildings were in extremely poor condition. The site became a popular destination with scrap metal collectors. In 2005 some of the buildings were listed among the most endangered monuments.

\subsubsection{Who undertook the redevelopment? What were the sources of finance for the redevelopment?}

When the period of subdued activity ended, the site was taken over by DIAMO, a state enterprise, which retained some of the buildings and rented out or sold the rest of them. Events took a turn for the better, when, in March 2002, the Blacksmith Shop together with the adjacent land was transferred to the St. Alexandr's Charity, an NGO. The Charity started using both parts of the building as its headquarters and as sheltered workshops (for textile workers and carpenter helpers). The Blacksmith Shop was donated to the Charity by the Charity of the Diocese of Ostrava-Opava, which acquired it in 1998 from the OKD coal mining company for the price of one million CZK [12].

In 2008, DIAMO transferred two buildings, the Coach House and the Administrative Building, including the adjacent land, to the city of Ostrava. In June 2008 the city of Ostrava transferred the property to the St. Alexandr's Charity for free.

The restoration of all three buildings was rather expensive and the Charity was absolutely unable to finance the restoration works from their internal sources. Substantial financial aid was provided by various subsidy programs, etc. Thanks to this support the Charity was able to bring back to life this outstanding industrial monument, which is no longer condemned to dilapidation and decay, unlike many other monuments. Table 2 shows the total costs associated with properties of St. Alexandr's Charity [3]. 


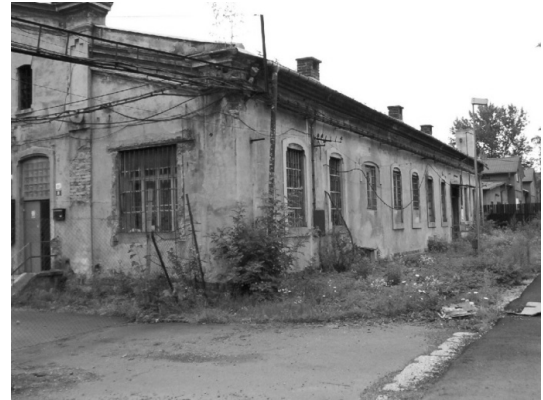

Figure 3: The "Coach House" prior to restoration 2003.

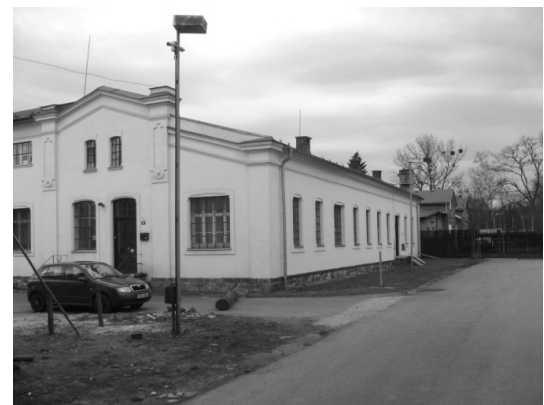

Figure 4: The "Coach House" after restoration 2010 (photos by B. Vojvodíková).

Table 2: $\quad$ Total reconstruction costs “Alexander”.

\begin{tabular}{|l|l|}
\hline Donor & Costs \\
\hline $\begin{array}{l}\text { External sources (MSR, MoLSA, City of Ostrava, MoC, The OKD } \\
\text { Foundation, The CIVILIA Foundation, The TIPSPORT Foundation, ROP) }\end{array}$ & $585,983 €$ \\
\hline Internal sources & $166,013 €$ \\
\hline$\%$ of external sources & $77.92 \%$ \\
\hline Total costs & $751,996 €$ \\
\hline
\end{tabular}

\subsection{What were the effects of the redevelopment?}

The restoration of the buildings actually meant that an industrial monument was saved at the last minute from possible complete decay. The fact that the properties were transferred to a charity, which intends to restore the buildings and start using them as sheltered workshops or sheltered housing for people with disabilities, means that the investment has a significant impact on reduction of unemployment of this particular group of people.

The restoration of these buildings also has a positive effect on the entire site. Since the buildings are located near the entrance to the premises, they also put in a negative light the owners of small businesses occupying other buildings on the site. Their clients no longer fear to enter the premises. It thus improves the condition of the small business, which, in return, can offer work opportunities to others.

\subsection{Actual impact - present function}

This part is based on an interview with director of the St. Alexandr's Charity. The positive effects can be divided into three main groups. First benefit is the possibility of employing people with disabilities. Yet, such institution could well work in any other place. The second significant effect is the fact that an 
industrial monument has thus been saved. However, this has not been a place of interest for tourists, although the number of visitors, who come to look at these buildings is increasing every year. The third, and most probably the most significant effect is that the citizens of Ostrava have gradually stopped considering this place as uninteresting and not worth moving to. Over the last three years the old mining houses in the neighbourhood have been restored, firms have started coming in, a riding hall has been built. Kunčičky is no longer a place, which one should avoid, on the contrary, the municipality starts drawing universal attention, which is a first step towards redevelopment of the area.

\section{Vošárna in Raduň}

\subsection{What were the past benefits derived from the site? What was its past function? What was done by way of development?}

Vošárna is a baroque building with a unique mansard roof dating back to the $18^{\text {th }}$ century. It originally served as a washhouse for the local gentry at the Radun chateau. It is located in Raduň, a municipality with a population of about 1,000 people. In the past, due to the location of the original castle, later the chateau, the municipality was one of the most important towns in the Opava Region. Vošárna was constructed between 1785 and 1820. It was built on land belonging to the chateau and offered work opportunities to locals [13].

\subsection{When did the site ceased to perform its function? How did it affect the environment?}

The building ceased to perform its function when the local gentry left the chateau in 1949. Over the years the chateau housed an agricultural high school and a warehouse. No one showed any interest in the Vošárna building, not even after the chateau was transferred to the National Heritage Institute in 1990 [14].

\subsection{Who undertook the redevelopment? What were the sources of finance for the redevelopment?}

For a long time the dilapidated building of Vošárna was a blot on the landscape of Raduň. Considering the poor condition of the building the National Heritage Institute listed it among the most endangered monuments in the Czech Republic. In 2007 the decaying building was bought by Rostislav Müller, a native of Raduň, who cared about what would become of the building. The Vošárna Civic Association, which was created to save the building, carried out the initial repair works. Afterwards, a project was set up to save Vošárna.

The project aims to restore the monument, which fits the definition of a brownfield site, and to transform it into a community centre (more information about system of reconstruction Václavík et.al. [15]). Table 3 shows the total costs associated with the restoration of the dilapidated historic monument [17]. 
Table 3: $\quad$ Total costs reconstruction Vošárna.

\begin{tabular}{|l|l|}
\hline Donor & Costs \\
\hline External sources (MoC, ROP, SAIF) & $266,053 €$ \\
\hline $\begin{array}{l}\text { Internal sources (Vošárna, civic association, civic association in Opava, } \\
\text { sponsors) }\end{array}$ & $23,408 €$ \\
\hline$\%$ of external sources & $91.91 \%$ \\
\hline Total costs & $289,460 €$ \\
\hline
\end{tabular}

Since Vošárna is listed among the national cultural monuments, all restoration works were watched by the National Heritage Institute, which oversaw that the restoration works did not corrupt the historic integrity of the building. Each month, during days of supervision, there were discussions about the construction works and about further steps, which were to be taken in compliance with the project. The important aspect was the cooperation with a construction company, which has extensive experience in restorations of cultural monuments.

\subsection{What were the effects of the redevelopment?}

The aim and the output of the project is the restored building of a community centre in Raduň. Vošárna is the centre of cultural and social life in Raduň and Vršovice, which is a neighbouring village. It is a place where people can do amateur sports, hold meetings of various clubs, societies and associations, and where cultural events can be organized. The targeted group are the inhabitants of Raduň and Vršovice.

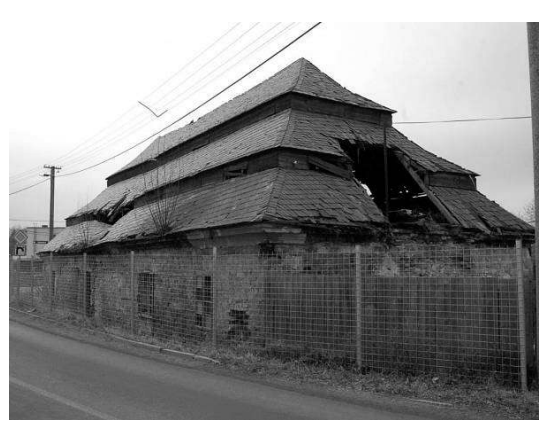

Figure 5: Building prior to Figure 6: restoration in 2007.

\subsection{Actual impact - present function}

This part is based on an interview with Mr Müller. The principal benefit of the restoration of Vošárna is its social impact. The social life in Raduň and Vršovice 
has long suffered from the lack of a place where people could meet and gather for group activities. Nowadays, the majority of the people living in Radun leave the village in the morning (to go to work or to school) and come back home in the evening, which slowly weakens social interactions and community ties. So, the fact that Vošárna offered a place for a maternity centre, for activities for smaller and bigger children, and for social gatherings contributes to better interpersonal relationships. And another significant benefit is naturally the fact that a valuable monument has been saved and is no longer a blot on the landscape of the village.

\section{Conclusion}

We could draw the following conclusion from the three examples. Small municipalities too have to deal with problems associated with disuse of some of their land. The problem is all the more serious if the previous development of the municipality was tightly connected with the original use of the land. Abandoned, decaying buildings do not generate any profit and present a blot on the landscape, hinder the possible development of the municipalities and constantly remind the inhabitants of the once glorious past. If the negative impression is corrected, further development is possible. The industrial park built on the site of the old coal mine "František" has new buildings, people are getting jobs and there are other services needed for the operation of the park and for the people who work there. The positive impact is also significant in the case of the old coal mine "Alexander". When the coal mine was closed, Kunčičky lost work opportunities as well as part of its population. The ugly, dilapidated buildings destroyed every hope of a future development and the interest of locals. Little by little, the restored buildings sparked the interest of the locals, as well as the interest of investors and business owners, who are slowly coming back to the region. As far as Vošárna is concerned, the principal benefit is not the creation of new work opportunities but the strengthening of interpersonal relationships in the village. A positive permanent development of a municipality has always been based on traditional relationships between the inhabitants. The Vošárna building helps to build up such relationships, which help keep the village from becoming merely a place to sleep in, without any interest extending beyond one's house; which would be unsustainable with regard to sustainable development. When the Czech Republic became a member of the European Union, it got the possibility of drawing money from European Union structural funds, which enabled NGOs and municipalities to undertake the redevelopment and restoration of old and unused buildings. However, it is necessary to emphasize the fact that at the beginning, the NGOs or municipalities had to invest their own money (as it was in the case of Vošárna, which was financed by a private person or in the case of the old coal mine "Alexander", which was financed by a charity). These persons or organizations invested their money without knowing in advance that they would receive subsidies. Thus, it was them alone who took the risk in being unable to finish the restoration works. In this context we must see that the role 
NGOs play in the development of municipalities is significant, indispensable, and nowadays also irreplaceable.

\section{List of abbreviations:}

MSR - Moravian-Silesian Region.

MoLSA - Ministry of Labour and Social Affairs of the Czech Republic.

MoC - Ministry of Culture of the Czech Republic.

ROP - Regional Operational Programme Moravia-Silesia.

SAIF - State Agricultural Intervention Fund.

OPIE - Operational Programme Industry and Enterprise.

\section{Acknowledgements}

This paper is prepared thanks to the project Brownfield Regeneration KnowHow Transfer BROWNTRANS, Project number: 113101614 which is supported by the Leonardo da Vinci Fund.

\section{References}

[1] Statistical office, www.czso.cz

[2] Bergatt-Jacson, J., Votoček, J. Inventatization brownfields sites in area Votice, 2003. www.brownfields.cz/wp-content/uploads/2007/11/ inventarizace_votice.pdf

[3] Klusáček, P., Krejčí, T., Kunc, J., Martinát, S., Nováková, E.: The postindustrial landscape in relation to local self-government in the Czech Republic. Moravian Geographical Reports, 2011 Vol. 19, No. 4, pp. 18-28.

[4] Pahlen, G., Glöckner, S., Sustainable regeneration of European brownfields sites, in Brownfield Sites II, Assessment, Rehabilitation and Development, WIT Press, 2004, ISBN:1-85312-719-1.

[5] Czech cadastral office, www.archivnimapy.cuzk.cz

[6] Coal mining in Ostravsko- Karvinském district, Anagram, Ostrava, 2003, ISBN 80-7342-016-3.

[7] Old maps, www.oldmaps.geolab.cz

[8] Horní Suchá, www.hornisucha.cz/prumyslova-zona-frantisek.html

[9] Matěj, M., Klát J. \& Korbelářová I., Cultural monuments in the OstravaKarvina district, National Heritage Institute, Department of regional planning in Ostrava, 2009, ISBN 978-80-85034-52-3.

[10] Regional Council of the Moravia Silesia Cohesion REGION (ROP MS). Realization of the projects, www.rr-moravskoslezsko.cz/realizujiprojekt/z-radunske-vosarny-bude-spolecenske-centrum

[11] Martinát, S., Dvořák, P., Frantál, B. \& Kol., in Brownfields - context and opportunities, Colliery Alexander - mirror of the past, opportunity of the future in Kunčičky: VŠB - Technical University of Ostrava, 2012. ISBN 978-80-7431-089-8. 
[12] Colliery Alexander second life; Czech Television, Rusty beauty. Online. www.ceskatelevize.cz/porady/10318003501-zrezivelakrasa/412235100091001-alexandruv-druhy-zivot/

[13] In village Raduň saved Vošárna; Czech Television, Regional news, Online. www.ceskatelevize.cz/ct24/regiony/97504-v-raduni-zachranili-vosarnu

[14] VOSARNA, www.vosarna.webnode.cz

[15] Václavík, V., Dvorský, T., Kušnerová, M., Daxner, J., Polyurethane Foam as Aggregate for Thermal Insulating Mortars and Lightweight Concrete, Środkowo-Pomorskie Towarzystwo Naukowe Ochrony Środowiska, 2012, ISSN 25-50-1506218X.

[16] Folta, P., Personal communication, 10 December 2012, Director of the St. Alexandr's Charity, Ostrava, Czech Republic.

[17] Müller, R., Personal communication, 20 November 2012, Founder NGOs Vošárna, Raduň, Czech Republic. 